\title{
Pemanfaatan Ternak dalam Pengendalian Nyamuk Vektor
}

\section{Penyakit}

\author{
Susi Soviana ${ }^{1}$, , Upik Kesumawati Hadi $^{1}$, Fahmi Khairi ${ }^{1}$, Supriyono ${ }^{1}$, Imam Hanafi ${ }^{2}$ \\ ${ }^{1}$ Divisi Parasitologi dan Entomologi Kesehatan, Departmen Ilmu Penyakit Hewan dan Kesehatan Masyarakat Veteriner, \\ Fakultas Kedokteran Hewan, Institut Pertanian Bogor, Bogor \\ ${ }^{2}$ Program Studi Parasitologi dan Entomologi Kesehatan, Sekolah Pascasarjana, Institut Pertanian Bogor, Bogor
}

\begin{abstract}
Mosquito are insects that cause the most health problems in society and animal, namely as nuisance insects and vector of various diseases such as malaria, dengue hemorrhagic fever, chikungunya, Japanese Encephalitis, dirofilariasis, filariasis, St. Louis Encephalitis and West Nile Virus. Control of mosquito as a vector with utilization of cattle (zooprophylaxis) needs to be done so the role of cattle is more optimize. This study aimed to know the effect of the placement of cattle around population to reduce contact between mosquitoes and human. Catching mosquitoes was done at home with two treatments, the house with cattle and house without cattle. Catching mosquitoes in human by bare leg collection method at indoor and outdoor and cattle were placed in a magoon trap. The result showed density of $C x$. sitiens are known as vector of Japanese Encephalitis in human at house with cattle 12.05 mosquitoes/man/hour, in human at house without cattle 16.31 mosquitoes/man/hour, and in cattle 54.38 mosquitoes/cattle/hour. Density of Anopheles are known as vector of malaria were caught showed placement of cattle reduce contact between mosquitoes and human. Density of An. sundaicus in human at house with cattle 0.03 mosquitoes $/ \mathrm{man} /$ hour, in human at house without cattle 0.01 mosquitoes $/ \mathrm{man} / \mathrm{hour}$, and in cattle $9.63 \mathrm{mosquitoes} / \mathrm{cattle} / \mathrm{hour}$. This research showed placement of cattle as zooprophylaxis media around population divert mosquitoes from human to animal.
\end{abstract}

\section{Keywords:}

mosquito, zooprophylaxis, cattle

\section{- PENDAHULUAN}

Nyamuk merupakan serangga yang paling banyak menimbulkan masalah kesehatan masyarakat dan hewan seperti malaria, demam berdarah dengue, chikungunya, Japanese Encephalitis, dirofilariasis, filariasis, St. Louis Encephalitis, dan West Nile Virus (Solichah 2009; Hadi \& Soviana 2010). Pemeliharaan hewan ternak di sekitar permukiman dapat menurunkan kontak nyamuk dengan manusia yang dikenal zooprofilaksis (Mardiana et al. 2011).

Penelitian zooprofilaksis menggunakan sapi untuk mengendalikan malaria dilaporkan Jan et al. (2001) di Pakistan dan Tirados et al. (2011) di Ethiopia. Walaupun banyak daerah endemis malaria di Indonesia dan zooprofilaksis telah dicanangkan dalam program nasional pengendalian malaria (Kemenkes RI 2012), tetapi belum dilaporkan pelaksanaannya di lapang. Penelitian ini untuk mengetahui keragaman jenis dan kelimpahan nyamuk yang menggigit orang dan sapi. Harapannya menjadi pertimbangan program pengendalian penyakit tular vektor nyamuk memanfaatkan ternak..

\section{- METODE}

Waktu dan Tempat Penelitian: Penelitian dilakukan di daerah endemis malaria Ds. Hanura, Kec. Padang Cermin, Kab. Pesawaran, Lampung. Identifikasi nyamuk di Lab. Entomologi Kesehatan, Fakultas Kedokteran Hewan, Institut Pertanian Bogor.
Penangkapan dan Preservasi Nyamuk: Penangkapan nyamuk dilakukan 5 kali pada 4 rumah ( 2 rumah dengan sapi dan 2 rumah tanpa sapi, sebagai kontrol) pada malam hari (selama 12 jam: 18.00-06.00). Penangkapan nyamuk dengan metode HLC (Human Landing Catches) menggunakan aspirator pada umpan orang dalam keadaan kaki terbuka (WHO 1993). Penangkapan nyamuk pada sapi dilakukan dalam $m a-$ goon trap / kurungan kelambu (6m x 6m x 2m), terdapat jendela masuk nyamuk dan pintu masuk untuk kolektor. $M a-$ goon trap ditempatkan diantara tempat perindukan nyamuk berjarak 10-20 m dari rumah. Penangkapan nyamuk di dalam dan luar rumah dilakukan secara bersamaan pada sapi. Nyamuk dimasukkan paper cup, ditutup kain kasa dan dimatikan menggunakan kloroform. Proses preservasi nyamuk cara kering menggunakan metode pinning (Hadi \& Soviana 2010).

Identifikasi Nyamuk: Identifikasi nyamuk dengan mikroskop stereo berdasar Kunci Bergambar (O’Connor \& Soepanto 2000), Kunci Identifikasi Nyamuk Culex (Depkes RI 2008a), dan Aedes (DepKes RI 2008b).

Analisis Data: Kepadatan nyamuk dalam MHD (man hour density) dan CHD (cattle hour density) dengan perhitungan:

Diterima: 15-06-2020 | Direvisi: 20-07-2020 | Disetujui: 25-07-2020

(C) 2020 CC-BY-SA. Ini adalah artikel Open Access yang didistribusikan berdasarkan ketentuan dari Creative Commons Attribution ShareAlike 4.0 International License (https://creativecommons.org/licenses/by-sa/4.0/). 
MHD $=\frac{\text { Jumlah Nyamuk Spesies Tertentu yang Tertangkap pada Orang }}{\text { Jumlah Kolektor } \times \frac{45}{60} \times \text { Jumlah Waktu (Jam) Penangkapan }}$

CHD $=\frac{\text { Jumlah Nyamuk Spesies Tertentu yang Tertangkap pada Sapi }}{\text { Jumlah Kolektor } \times \frac{45}{60} \times \text { Jumlah Waktu (Jam) Penangkapan }}$

\section{- HASIL DAN PEMBAHASAN}

\section{Keanekaragaman Nyamuk pada Orang dan Sapi}

Nyamuk yang tertangkap terdiri atas 6 spesies Culex, 5 spesies Anopheles, 1 spesies Armigeres, 2 spesies Aedes (Tabel 1). Cx. sitiens pradewasa terdapat pada genangan air yang terkena cahaya matahari, lubang-lubang kecil, danau, sumur, rawa-rawa, tambak udang, dan bekas galian tambang timah (Prummongkol et al. 2011). Cx. tritaeniorhynchus bersifat antropozoofilik ditemukan di lahan persawahan yang terdapat ternak di sekitar permukiman (Dharma et al. 2004, Ginanjar 2011). Anopheles yang tertangkap adalah $A n$. vagus, An. sundaicus, An. barbirostris, An. vagus dan An. sundaicus merupakan vektor malaria di daerah pantai (Munif 2009). An. vagus dan An. barbirostris ditemukan pada lahan persawahan (Prastowo 2011).

Tabel 1 Jenis nyamuk yang tertangkap pada orang dan sapi

\begin{tabular}{lrc}
\hline Spesies & Jumlah & Persentase (\%) \\
\hline Cx. sitiens & 4300 & 63,70 \\
Cx. tritaeniorhynchus & 1596 & 23,64 \\
An. sundaicus & 337 & 4,99 \\
An. vagus & 207 & 3,07 \\
Cx. quinquefasciatus & 117 & 1,73 \\
An. barbirostris & 64 & 0,95 \\
An. subpictus & 53 & 0,79 \\
An. aconitus & 28 & 0,41 \\
Ar. subalbatus & 25 & 0,37 \\
Cx. hutchinsoni & 14 & 0,21 \\
Cx. fuscocephalus & 4 & 0,06 \\
Cx. bitaeniorhynchus & 2 & 0,03 \\
Ae. aegypti & 2 & 0,03 \\
Ae. albopictus & 1 & 0,01 \\
\hline Total & 6750 & 100 \\
\hline
\end{tabular}

Tabel 2 Nilai MHD dan CHD jenis-jenis nyamuk yang tertangkap pada umpan orang dan umpan sapi

\begin{tabular}{lccr}
\hline \multirow{4}{*}{ Spesies } & \multicolumn{3}{c}{ MHD/ CHD } \\
\cline { 2 - 4 } & Rumah + Sapi & Rumah - Sapi & Sapi \\
\hline Cx. sitiens & 12,05 & 16,31 & 54,38 \\
Cx. tritaeniorhynchus & 1,32 & 1,37 & 38,17 \\
Cx. quinquefasciatus & 0,96 & 0,29 & 0,27 \\
Cx. fuscocephalus & 0,01 & 0,03 & 0,00 \\
Cx. hutchinsoni & 0,09 & 0,07 & 0,00 \\
Cx. bitaeniorhynchus & 0,00 & 0,03 & 0,00 \\
An. sundaicus & 0,03 & 0,01 & 9,63 \\
An. vagus & 0,01 & 0,01 & 6,12 \\
An. aconitus & 0,00 & 0,00 & 0,76 \\
An. barbirostris & 0,01 & 0,00 & 1,93 \\
An. subpictus & 0,00 & 0,00 & 1,49 \\
Ar. subalbatus & 0,15 & 0,01 & 0,33 \\
Ae. aegypti & 0,03 & 0,00 & 0,00 \\
Ae. albopictus & 0,01 & 0,00 & 0,00 \\
\hline Keterangan: nilai $0,00=$ jumlah sangat rendah/tidak ditemukan.
\end{tabular}

\section{Kepadatan Nyamuk pada Umpan Orang dan Sapi}

Kepadatan nyamuk pada orang dengan rumah ada sapi (Rumah + sapi), rumah tanpa sapi (Rumah - sapi) dan pada sapi (Tabel 2). Kepadatan nyamuk yang tertangkap pada orang di rumah yang ditempatkan sapi lebih rendah dibanding pada orang di rumah yang tidak ditempatkan sapi.
New Zealand Biosecure (2006) menyebutkan $C x$. sitiens beraktivitas nokturnal pada inang manusia, ayam, kuda, domba, unggas, babi, dan sapi. Munif (2009) dan Prastowo (2011) melaporkan vektor malaria An. vagus dan $A n$. sundaicus bersifat zoofilik di daerah pantai, namun dapat menggigit manusia jika tidak ada hewan. Sapi berperan sebagai media zooprofilaksis yang efektif mengalihkan gigitan nyamuk dari ke manusia ke hewan.

\section{- SIMPULAN}

Penempatan sapi sebagai media zooprofilaksis mampu mengalihkan angka gigitan nyamuk pada manusia, sehingga dapat dijadikan sebagai metode pengendalian nyamuk di daerah endemis penyakit tular vektor nyamuk.

\section{— INFORMASI PENULIS}

Penulis untuk Korespondensi

*SS: s_soviana@indo.net.id

Departemen Ilmu Penyakit Hewan dan Kesehatan Masyarakat Veteriner, Fakultas Kedokteran Hewan, Institut Pertanian Bogor, Jl. Agatis Kampus IPB Dramaga Bogor 16680.

\section{- PUSTAKA ACUAN}

[Depkes RI] Departemen Kesehatan Republik Indonesia. 2008a. Kunci Identifikasi Nyamuk Culex. Jakarta (ID): Dit. Jen. PP \& PL.

[Depkes RI] Departemen Kesehatan Republik Indonesia. 2008b. Kunci Identifikasi Nyamuk Aedes. Jakarta (ID): Dit. Jen. PP \& PL.

Dharma W, Hoedojo, Abikusno RMN, Suripriastuti, A Inggrid AT, Sutanto BA. 2004. Survei nyamuk di Desa Marga Mulya, Kec. Mauk, Tangerang. J Kedokter Trisakti. 23(2):57-62.

Ginanjar RA. 2011. Densitas dan perilaku nyamuk (Diptera: Culicidae) di Desa Bojong Rangkas Kabupaten Bogor [skripsi]. Bogor (ID): Institut Pertanian Bogor

Hadi UK, Soviana S. 2010. Ektoparasit Pengenalan, Identifikasi, dan Pengendaliannya. Bogor (ID): IPB Pr.

Jan AH, Ahmad M, Khan SU. 2001. Zooprophylaxis with special reference to malaria in human population. J. Pakistan Vet.21(1):52-54

[Kemenkes RI] Kementerian Kesehatan Republik Indonesia. 2012. Pedoman Penggunaan Insektisida (Pestisida) dalam Pengendalian Vektor. Jakarta (ID): Kementerian Kesehatan RI.

Mardiana, Lestari EW, Perwitasari D. 2011. Faktor-faktor yang mempengaruhi kejadian filariasis. J Ekol Indones. 10(2): 83-92.

Munif A. 2009. Nyamuk vektor malaria dan hubungannya dengan aktivitas kehidupan manusia di Indonesia. Aspirator. Vol.1(2):94-102.

New Zealand Biosecure. 2006. Culex sitiens. Auckland (NZ): Entomology Laboratory SMS (Southern Monitoring Service). 29 Nov 2006.

O'Connor CT, Supanto A.2000. Kunci Bergambar Nyamuk Anopheles Betina Di Indonesia. Depkes RI. Dit.Jen P2M \& PLP. Jakarta (ID): 40 hal.

Prastowo D, Anggraini YM. 2011. Dinamika populasi nyamuk yang diduga sebagai vektor di Kecamatan Rojolele, Kabupaten Kebuman, Jawa Tengah. Jurnal Vektora. 4(2):83-97.

Prummongkol S, Panasoponkul, Apiwathnasorn, Uthai UL. 2011. Biology of Culex sitiens, a predominant mosquito in Phang Nga, Thailand after tsunami. J Insect Scienc. 12(11):1-8.

Solichah Z. 2009. Ancaman dari nyamuk Culex sp. yang terabaikan. Balaba. 5(1):21-23.

Tirados I, Gibson G, Young S, Torr S. 2011. Are herders protected by their herds? An experimental analysis of zooprophylaxis againts the malaria vector Anopheles arabiensis. Malar J. 10(1): 68. Tersedia pada: http://www.malariajournal.com/content/10/1/68.

WHO. 1993. Global Malaria Control. Bulletin WHO, 71(3-4): 281-284. 